Jurnal Qua Teknika, Vol. 8 No. 2 September 2018

p-ISSN: 2088-2424; e-ISSN: 2527-3892

Fakultas Teknik Universitas Islam Balitar, Blitar

Http://qua.unisbablitar.ejournal.web.id; Email; quateknika@Gmail.com

Subaidillah Fansuri, Anita Intan Nura Diana. 2018. Karakteristik Komoditas Batu Kerikil dan Pasir Hitam untuk Bahan Bangunan di Kabupaten Sumenep.

Jurnal Qua Teknika, (2018), 8(2) : 43-51

\title{
KARAKTERISTIK KOMODITAS BATU KERIKIL DAN PASIR HITAM UNTUK BAHAN BANGUNAN DI KABUPATEN SUMENEP
}

\author{
Subaidillah Fansuri ${ }^{1}$, Anita Intan Nura Diana ${ }^{2}$ \\ Fakultas Teknik. Universitas Wiraraja \\ Sumenep, 69451, Indonesia \\ 1e-mail : subaidillah.sd@gmail.com \\ 2e-mail : anita@wiraraja.ac.id
}

\begin{abstract}
ABSTRAK
Pertumbuhan jumlah penduduk Indonesia yang semakin bertambah, berbanding lurus dengan pertambahan kebutuhan penduduk terhadap sandang, pangan dan papan. Seiring dengan bertambahnya jumlah penduduk maka semakin meningkat jumlah kebutuhan masyarakat dalam meningkatkan taraf hidup yang layak misalnya pembangunan infrastruktur jalan, bangunan gedung dsb. Pembangunan infrastruktur pasti membutuhkan material yang bermacam-macam seperti bahan campuran beton, membutuhkan pasir, kerikil, semen dan air. Karakteristik sifat beton memiliki kuat tekan tinggi namun lemah dalam kuat tarik maka dari itu dalam proses pembuatan beton dibutuhkan bahan yang bermutu untuk menjaga kualitas beton.

Data yang dibutuhkan dalam penelitian ini adalah data primer. Teknik yang digunakan untuk mengumpulkan data dalam penelitian ini adalah metode eksperimental. Dalam hal ini peneliti melakukan uji laboratorium yaitu percobaan kadar air pasir; percobaan berat jenis pasir; percobaan berat voleme pasir; test kebersihan pasir terhadap lumpur (endapan); test kebersihan pasir terhadap lumpur (pencucian); percobaan kadar air batu pecah; percobaan berat jenis batu pecah; percobaan berat voleme batu pecah; test kebersihan batu pecah terhadap lumpur (pencucian); Test Keausan Agregat Kasar. Teknik analisis data akan dilakukan dengan langkah-langkah berikut : 1) Survey lokasi; 2) Pengambilan sampel; 3) Uji laboratorium.

Hasil percobaan kadar air agregat kasar untuk Desa Batuan 5,02\%; Desa Batu Putih 1,83\%; Desa Dasuk 2,08\%; Desa Rubaru 1,93\%; Desa Lenteng 2,04\%. Hasil percobaan berat jenis kering agregat kasar untuk Desa Batuan 2,42 gr; Desa Batu Putih 2,39 gr; Desa Dasuk 2,45 gr; Desa Rubaru 2,53 gr; Desa Lenteng 2,32 gr. Hasil percobaan berat volume agregat kasar untuk Desa Batuan 1814,5 Kg/m3; Desa Batu Putih 2230,5 Kg/m3; Desa Dasuk 1977,5 Kg/m3; Desa Rubaru 2075,5 Kg/m3; Desa Lenteng 1852,5 Kg/m3. Hasil percobaan kebersihan agregat terhadap kadar lumpur agregat kasar untuk Desa Batuan $1 \%$; Desa Batu Putih 0,5\% ; Desa Dasuk 0,5 \%; Desa Rubaru 0,5 \%; Desa Lenteng 0,7 \%. Hasil percobaan keausan agregat kasar untuk Desa Batuan 19,8 \%; Desa Batu Putih 29,6 \% ; Desa Dasuk 26,2 \%; Desa Rubaru 24,8 \%; Desa Lenteng 25,6 \%.

Hasil percobaan kadar air agregat halus untuk pasir pasuruan $14,15 \%$; dan pasir pasirian 8,93\%. Hasil percobaan berat jenis kering agregat halus untuk pasir pasuruan 2,27gr ; dan pasir pasirian 2,8 gr. Hasil percobaan berat volume agregat halus untuk pasir pasuruan $1459,3 \mathrm{Kg} / \mathrm{m} 3$; dan pasir pasirian $1749,3 \mathrm{Kg} / \mathrm{m} 3$. Hasil percobaan kadar lumpur (pengendapan) agregat halus untuk pasir pasuruan 5,26 \%; dan pasir pasirian $9 \%$. Hasil percobaan kadar lumpur (pencucian) agregat halus untuk pasir pasuruan 6,26\%; dan pasir pasirian 7,9\%.
\end{abstract}

Kata Kunci: Batu Kerikil, Pasir Hitam, Bahan Bangunan

\section{PENDAHULUAN}

Beton biasanya memiliki campuran agregat sangat tinggi. Berdasarkan pengalaman Tri Mulyono (2005:65), komposisi agregat tersebut berkisar 60\%-70\% dari berat campuran beton. Agregat itu sendiri hanya digunakan sebagai bahan pengisi akan tetapi dikarenakan komposisinya yang cukup besar, agregat inipun menjadi penting. Karena itu agregat itu sendiri perlu dipelajari karakteristik agregat dimana agregat itu sendiri akan menentukan sifat mortar dan beton yang dihasilkan.

Secara umum, agregat dibedakan berdasarkan ukurannya, yaitu, agregat kasar dan agregat halus. Menurut SNI 03-2847-2002, bahwa agregat halus merupakan agregat yang mempunyai ukuran butir maksimum sebesar 5,00 mm dan agregat kasar yang mempunyai ukuran butir antara 5,00 mm sampai $40 \mathrm{~mm}$.

Di Kabupaten Sumenep terdapat potensi untuk agregat kasar, dilihat dari adanya kegiatan pertambangan di beberapa lokasi di Kabupaten Sumenep, dimana pekerjaan proyek bangunan di Kabupaten Sumenep kebanyakan masih menggunakan material agregat kasar lokal dari tambang-tambang yang ada di Kabupaten Sumenep itu sendiri. 
Jurnal Qua Teknika, Vol. 8 No. 2 September 2018

p-ISSN: 2088-2424; e-ISSN: 2527-3892

Fakultas Teknik Universitas Islam Balitar, Blitar

Http://qua.unisbablitar.ejournal.web.id; Email; quateknika@Gmail.com

Subaidillah Fansuri, Anita Intan Nura Diana. 2018. Karakteristik Komoditas Batu Kerikil dan Pasir Hitam untuk Bahan Bangunan di Kabupaten Sumenep.

Jurnal Qua Teknika, (2018), 8(2) : 43-51

Agregat kasar di Kabupaten Sumenep itu dihasilkan dari lima lokasi tambang terbesar yang berasal dari daerah Desa Batuan (belakang asta tinggi) Kec.Batuan, Desa Batu Putih Kec.Batu Putih, Desa Dasuk Kec.Dasuk, Desa Duko Kec.Rubaru, Desa Ellak Daya Kec.Lenteng.

Berdasarkan pembahasan diatas peneliti bermaksud untuk mengetahui karakteristik material lokal yaitu kerikil di beberapa lokasi yang ada di Kabupaten Sumenep dan karakteristik pasokan pasir yang masuk ke Kabupaten Sumenep, sehingga peneliti mengangkat judul "Karakteristik Komoditas Batu Kerikil dan Pasir Hitam untuk Bahan Bangunan Di Kabupaten Sumenep".

\section{METODE PENELITIAN}

Penelitian akan dilaksanakan di Laboratorium Teknik Sipil, Program Studi Teknik Sipil, Fakultas Teknik. Universitas Wiraraja Sumenep.

Penelitian ini akan mengukur karakteristik agregat kasar yaitu kerikil dan agregat halus yaitu pasir yang ada di Kabupaten Sumenep. Adapun peubah yang akan diamati yaitu :

Tabel 1. Peubah yang diamati

\begin{tabular}{|c|c|c|}
\hline No & Jenis Agregat & Pengukuran \\
\hline 1 & $\begin{array}{l}\text { Agregat Kasar (Kerikil) } \\
5 \text { lokasi yaitu : Batuan, Batu } \\
\text { Putih, Duko, Ellak Daya, } \\
\text { Dasuk }\end{array}$ & 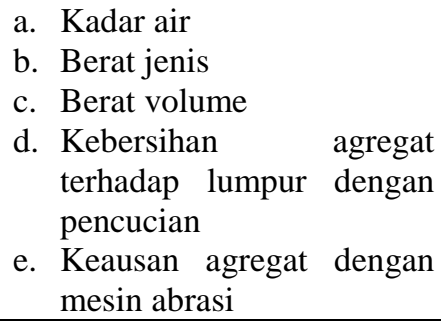 \\
\hline 2 & $\begin{array}{l}\text { Agregat Halus (Pasir Hitam) } \\
\text { Pasir Pasuruan \& Pasirian } \\
\text { Lumajang }\end{array}$ & $\begin{array}{l}\text { a. Kadar air } \\
\text { b. Berat jenis } \\
\text { c. Berat volume } \\
\text { d. Kebersihan pasir terhadap } \\
\text { lumpur dengan cara } \\
\text { pengendapan } \\
\text { e. Kebersihan pasir terhadap } \\
\text { lumpur dengan cara } \\
\text { pencucian }\end{array}$ \\
\hline
\end{tabular}

Berdasarkan tujuan penelitian, analisis yang diperlukan dalam penelitian ini adalah analisis statistik deskriptif. Analisis ini digunakan untuk menguji kualitas bahan material untuk pekerjaan konstuksi di Kabupaten Sumenep

Hal yang dianalisis adalah kualitas dari bahan material untuk pekerjaan kontruksi di kabupaten sumenep. Analisis data ini dilakukan dengan pengujian laboratorium yang ada di Universitas Wiraraja Sumenep. Langkahlangkah analisis yang dilakukan adalah sebagai berikut:

1. Survey lokasi

2. Pengambilan sampel

3. Uji laboratorium

\section{HASIL DAN PEMBAHASAN}

\section{Pengujian Material Agregat Kasar (Kerikil)}

Pengujian Kadar Air

Pengujian agregat kasar di laboratorium teknologi bahan untuk mengetahui karakteristik atau mutu dari agregat kasar (kerikil) yaitu percobaan kadar air kerikil, yang mana dalam percobaan ini untuk mengetahui berapa kandungan kadar air dalam kerikil yang berasal dari Desa Batuan (belakan asta tinggi) Kecamatan Batuan, Desa Batu Putih Kecamatan Batu Putih, Desa Dasuk Kecamatan Dasuk, Desa Duko Kecamatan Rubaru, Desa Ellak Daya Kecamatan Lenteng, berikut tabel data hasil percobaan kadar air yang di dapat dari hasil pengujian di laboratorium teknologi bahan Universitas Wiraraja Sumenep. 
Jurnal Qua Teknika, Vol. 8 No. 2 September 2018

p-ISSN: 2088-2424; e-ISSN: 2527-3892

Fakultas Teknik Universitas Islam Balitar, Blitar

Http://qua.unisbablitar.ejournal.web.id; Email; quateknika@ Gmail.com

Subaidillah Fansuri, Anita Intan Nura Diana. 2018. Karakteristik Komoditas Batu Kerikil dan Pasir Hitam untuk Bahan Bangunan di Kabupaten Sumenep.

Jurnal Qua Teknika, (2018), 8(2) : 43-51

Tabel 2. Hasil percobaan kadar air

\begin{tabular}{|l|c|c|c|c|c|}
\hline \multicolumn{1}{|c|}{$\begin{array}{c}\text { DAERAH } \\
\text { PERCOBAAN }\end{array}$} & $\begin{array}{c}\text { Desa Batuan } \\
\text { (Belakang asta } \\
\text { tinggi) }\end{array}$ & $\begin{array}{c}\text { Desa Batu } \\
\text { Putih }\end{array}$ & Desa Dasuk & $\begin{array}{c}\text { Desa Duko- } \\
\text { Rubaru }\end{array}$ & $\begin{array}{c}\text { Desa Ellak } \\
\text { Daya- } \\
\text { Lenteng }\end{array}$ \\
\hline $\begin{array}{l}\text { Berat kerikil asli } \\
\left(\mathrm{W}_{1}\right)\end{array}$ & $500 \mathrm{gr}$ & $500 \mathrm{gr}$ & $500 \mathrm{gr}$ & $500 \mathrm{gr}$ & $500 \mathrm{gr}$ \\
\hline $\begin{array}{l}\text { Berat kerikil kering } \\
\text { oven }\left(\mathrm{W}_{2}\right)\end{array}$ & $497,5 \mathrm{gr}$ & $491 \mathrm{gr}$ & $489,8 \mathrm{gr}$ & $490,5 \mathrm{gr}$ & $490 \mathrm{gr}$ \\
\hline $\begin{array}{l}\text { Kelembaban kerikil } \\
(\%)\end{array}$ & $5,02 \%$ & $1,83 \%$ & $2,08 \%$ & $1,93 \%$ & $2,04 \%$ \\
\hline
\end{tabular}

Hasil penelitian yang kami lakukan dalam percobaan kadar air kerikil ini didapatkan hasil kandungan kadar air kerikil yang berbeda-beda dari setiap daerah kerikil yang kami teliti.

Pengujian Berat Jenis

Pengujian agregat kasar di laboratorium teknologi bahan yang selanjutnya untuk mengetahui karakteristik atau mutu dari agregat kasar (kerikil) yaitu percobaan berat jenis kerikil, yang mana dalam percobaan ini untuk mengetahui berat jenis kering,berat jenis SSD (Saturated Surface dry), berat jenis semu dan penyerapan air pada kerikil yang berasal dari Desa Batuan (belakang asta tinggi), Desa Batu Putih, Desa Dasuk, Desa Duko, Desa Ellak Daya, berikut tabel data hasil percobaan berta jenis yang di dapat dari hasil pengujian di laboratorium teknologi bahan Universitas Wiraraja Sumenep.

Tabel 3. Hasil Percobaan berat jenis

\begin{tabular}{|l|c|c|c|c|c|}
\hline \multicolumn{1}{|c|}{$\begin{array}{c}\text { DAERAH } \\
\text { PERCOBAAN }\end{array}$} & $\begin{array}{c}\text { Desa Batuan } \\
\text { (Belakang asta } \\
\text { tinggi) }\end{array}$ & Desa Batu Putih & Desa Dasuk & $\begin{array}{c}\text { Desa Duko- } \\
\text { Rubaru }\end{array}$ & $\begin{array}{c}\text { Desa Ellak } \\
\text { Daya }\end{array}$ \\
\hline $\begin{array}{l}\text { Berat benda uji kering } \\
\text { permukaan jenuh }\left(\mathrm{W}_{1}\right)\end{array}$ & $500 \mathrm{gr}$ & $500 \mathrm{gr}$ & $500 \mathrm{gr}$ & $500 \mathrm{gr}$ & $500 \mathrm{gr}$ \\
\hline $\begin{array}{l}\text { Berat ember dalam air } \\
\left(\mathrm{W}_{2}\right)\end{array}$ & $590 \mathrm{gr}$ & $590 \mathrm{gr}$ & $590 \mathrm{gr}$ & $590 \mathrm{gr}$ & $590 \mathrm{gr}$ \\
\hline $\begin{array}{l}\text { Berat ember }+ \text { benda } \\
\text { uji dalam air }\left(\mathrm{W}_{3}\right)\end{array}$ & $890 \mathrm{gr}$ & $885 \mathrm{gr}$ & $890 \mathrm{gr}$ & $896 \mathrm{gr}$ & $881 \mathrm{gr}$ \\
\hline $\begin{array}{l}\text { Berat kerikil kering } \\
\text { oven }\left(\mathrm{W}_{4}\right)\end{array}$ & $485 \mathrm{gr}$ & $490 \mathrm{gr}$ & $490 \mathrm{gr}$ & $491 \mathrm{gr}$ & $485 \mathrm{gr}$ \\
\hline $\begin{array}{l}\text { Berat jenis kering }=\mathrm{W}_{4} \\
/\left(\mathrm{W}_{2}+\mathrm{W}_{1}-\mathrm{W}_{3}\right)\end{array}$ & $2,42 \mathrm{gr}$ & $2,39 \mathrm{gr}$ & $2,45 \mathrm{gr}$ & $2,53 \mathrm{gr}$ & $2,32 \mathrm{gr}$ \\
\hline $\begin{array}{l}\text { Berat Jenis } \mathrm{SSD}=\mathrm{W}_{1} / \\
\left(\mathrm{W}_{2}+\mathrm{W}_{1}-\mathrm{W}_{3}\right)\end{array}$ & $2,5 \mathrm{gr}$ & $2,43 \mathrm{gr}$ & $2,5 \mathrm{gr}$ & $2,57 \mathrm{gr}$ & $2,39 \mathrm{gr}$ \\
\hline $\begin{array}{l}\text { Berat Jenis Semu }=\mathrm{W}_{4} \\
/\left(\mathrm{W}_{2}+\mathrm{W}_{4}-\mathrm{W}_{3}\right)\end{array}$ & $2,62 \mathrm{gr}$ & $2,51 \mathrm{gr}$ & $2,57 \mathrm{gr}$ & $2,65 \mathrm{gr}$ & $2,5 \mathrm{gr}$ \\
\hline $\begin{array}{l}\text { Penyerapan }=\left(\left(\mathrm{W}_{1-}\right.\right. \\
\left.\left.\mathrm{W}_{4}\right) / \mathrm{W}_{4}\right) \times 100 \%\end{array}$ & $3,09 \%$ & $2,04 \%$ & $2,04 \%$ & $1,83 \%$ & $3,09 \%$ \\
\hline
\end{tabular}

Hasil penelitian yang kami lakukan dalam percobaan berat jenis kerikil ini didapatkan hasil berat jenis kering kerikil, berat jenis SSD (Saturated Surface dry) kerikil, berat jenis semu kerikil dan penyerapan air pada kerikil yang berbeda-beda dari setiap daerah kerikil yang kami teliti 
Jurnal Qua Teknika, Vol. 8 No. 2 September 2018

p-ISSN: 2088-2424; e-ISSN: 2527-3892

Fakultas Teknik Universitas Islam Balitar, Blitar

Http://qua.unisbablitar.ejournal.web.id; Email; quateknika@ Gmail.com

Subaidillah Fansuri, Anita Intan Nura Diana. 2018. Karakteristik Komoditas Batu Kerikil dan Pasir Hitam untuk Bahan Bangunan di Kabupaten Sumenep.

Jurnal Qua Teknika, (2018), 8(2) : 43-51

Pengujian Berat Volume

Pengujian agregat kasar di laboratorium teknologi bahan untuk mengetahui karakteristik atau mutu dari agregat kasar (kerikil) yaitu percobaan berat jenis kerikil, yang mana dalam percobaan ini untuk mengetahui berat volume kerikil yang berasal dari Desa Batuan (belakan asta tinggi), Desa Batu Putih, Desa Dasuk, Desa Duko, Desa Ellak Daya, berikut tabel data hasil percobaan berat volume yang di dapat dari hasil pengujian di laboratorium teknologi bahan Universitas Wiraraja Sumenep.

Tabel 4. Hasil percobaan berat volume daerah Batuan

\begin{tabular}{|c|c|c|}
\hline DAERAH PERCOBAAN & $\begin{array}{c}\text { Desa Batuan } \\
\text { (Belakang asta tinggi) } \\
\text { TANPA ROJOKAN }\end{array}$ & $\begin{array}{c}\text { Desa Batuan } \\
\text { (Belakang asta tinggi) } \\
\text { DENGAN ROJOKAN }\end{array}$ \\
\hline Berat silinder $\left(\mathrm{W}_{1}\right)-\mathrm{kg}$ & $5,605 \mathrm{~kg}$ & $5,605 \mathrm{~kg}$ \\
\hline Berat batu pecah $\left(\mathrm{W}_{2}-\mathrm{W}_{1}\right)$ & $18,15 \mathrm{~kg}$ & $19,46 \mathrm{~kg}$ \\
\hline Berat silinder + batu pecah $\left(\mathrm{W}_{2}\right)-\mathrm{kg}$ & $5,605+18,15=23,75 \mathrm{~kg}$ & $5,605+19,46=25,06 \mathrm{~kg}$ \\
\hline Volume silinder $(\mathrm{V})$ - liter & 10 liter $=0,01 \mathrm{~m} 3$ & 10 liter $=0,01 \mathrm{~m} 3$ \\
\hline Berat volume $\left(\mathrm{W}_{2}-\mathrm{W}_{1}\right) / \mathrm{V}$ & $\begin{array}{c}(23,75-5,605) / 0,01 \\
=1.814,5 \mathrm{~kg} / \mathrm{m} 3\end{array}$ & $\begin{array}{c}(25,06-5,605) / 0,01 \\
=1.945,5 \mathrm{~kg} / \mathrm{m} 3\end{array}$ \\
\hline
\end{tabular}

Sumber: Hasil Uji Laboratorium Teknologi Bahan Fakultas Teknik Universitas Wiraraja Sumenep

Tabel 5. Hasil percobaan berat volume daerah Batu Putih

\begin{tabular}{|l|c|c|}
\hline \multicolumn{1}{|c|}{ DAERAH PERCOBAAN } & $\begin{array}{c}\text { Desa Batu Putih } \\
\text { TANPA ROJOKAN }\end{array}$ & $\begin{array}{c}\text { Desa Batu Putih } \\
\text { DENGAN ROJOKAN }\end{array}$ \\
\hline Berat silinder $\left(\mathrm{W}_{1}\right)-\mathrm{kg}$ & $5,605 \mathrm{~kg}$ & $5,605 \mathrm{~kg}$ \\
\hline Berat batu pecah $\left(\mathrm{W}_{2}-\mathrm{W}_{1}\right)$ & $18,30 \mathrm{~kg}$ & $22,31 \mathrm{~kg}$ \\
\hline Berat silinder + batu pecah $\left(\mathrm{W}_{2}\right)-\mathrm{kg}$ & $5,605+18,30=23,90 \mathrm{~kg}$ & $5,605+22,31=27,91 \mathrm{~kg}$ \\
\hline Volume silinder $(\mathrm{V})-$ liter & 10 liter $=0,01 \mathrm{~m} 3$ & 10 liter $=0,01 \mathrm{~m} 3$ \\
\hline Berat volume $\left(\mathrm{W}_{2}-\mathrm{W}_{1}\right) / \mathrm{V}$ & $\begin{array}{c}(23,90-5,605) / 0,01 \\
=1.829,5 \mathrm{~kg} / \mathrm{m} 3\end{array}$ & $\begin{array}{c}(27,91-5,605) / 0,01 \\
=2.230,5 \mathrm{~kg} / \mathrm{m} 3\end{array}$ \\
\hline
\end{tabular}

Sumber: Hasil Uji Laboratorium Teknologi Bahan Fakultas Teknik Universitas Wiraraja Sumenep 
Jurnal Qua Teknika, Vol. 8 No. 2 September 2018

p-ISSN: 2088-2424; e-ISSN: 2527-3892

Fakultas Teknik Universitas Islam Balitar, Blitar

Http://qua.unisbablitar.ejournal.web.id; Email; quateknika@ Gmail.com

Subaidillah Fansuri, Anita Intan Nura Diana. 2018. Karakteristik Komoditas Batu Kerikil dan Pasir Hitam untuk Bahan Bangunan di Kabupaten Sumenep.

Jurnal Qua Teknika, (2018), 8(2) : 43-51

Tabel 6. Hasil percobaan berat volume daerah Dasuk

\begin{tabular}{|c|c|c|}
\hline DAERAH PERCOBAAN & $\begin{array}{c}\text { Desa Dasuk } \\
\text { TANPA ROJOKAN }\end{array}$ & $\begin{array}{c}\text { Desa Dasuk } \\
\text { DENGAN ROJOKAN }\end{array}$ \\
\hline Berat silinder $\left(\mathrm{W}_{1}\right)-\mathrm{kg}$ & $5,605 \mathrm{~kg}$ & $5,605 \mathrm{~kg}$ \\
\hline Berat batu pecah $\left(\mathrm{W}_{2}-\mathrm{W}_{1}\right)$ & $18,33 \mathrm{~kg}$ & $19,77 \mathrm{~kg}$ \\
\hline Berat silinder + batu pecah $\left(\mathrm{W}_{2}\right)-\mathrm{kg}$ & $5,605+18,33=23,93 \mathrm{~kg}$ & $5,605+19,77=25,38 \mathrm{~kg}$ \\
\hline Volume silinder $(\mathrm{V})-$ liter & 10 liter $=0,01 \mathrm{~m} 3$ & 10 liter $=0,01 \mathrm{~m} 3$ \\
\hline Berat volume $\left(\mathrm{W}_{2}-\mathrm{W}_{1}\right) / \mathrm{V}$ & $\begin{array}{c}(23,93-5,605) / 0,01 \\
=1.832,5 \mathrm{~kg} / \mathrm{m} 3\end{array}$ & $\begin{array}{c}(25,38-5,605) / 0,01 \\
=1.977,5 \mathrm{~kg} / \mathrm{m} 3\end{array}$ \\
\hline
\end{tabular}

Sumber: Hasil Uji Laboratorium Teknologi Bahan Fakultas Teknik Universitas Wiraraja Sumenep

Tabel 7. Hasil percobaan berat volume daerah Rubaru

\begin{tabular}{|c|c|c|}
\hline DAERAH PERCOBAAN & $\begin{array}{c}\text { Desa Duko Rubaru } \\
\text { TANPA ROJOKAN }\end{array}$ & $\begin{array}{c}\text { Desa Duko Rubaru } \\
\text { DENGAN ROJOKAN }\end{array}$ \\
\hline Berat silinder $\left(\mathrm{W}_{1}\right)-\mathrm{kg}$ & $5,605 \mathrm{~kg}$ & $5,605 \mathrm{~kg}$ \\
\hline Berat batu pecah $\left(\mathrm{W}_{2}-\mathrm{W}_{1}\right)$ & $18,63 \mathrm{~kg}$ & $20,76 \mathrm{~kg}$ \\
\hline Berat silinder + batu pecah $\left(\mathrm{W}_{2}\right)-\mathrm{kg}$ & $\begin{array}{c}5,605+18,63=24,23 \mathrm{~kg} \\
\text { Volume silinder }(\mathrm{V})-\text { liter }\end{array}$ 10 liter $=0,01 \mathrm{~m} 3^{5,605+20,76=26,36 \mathrm{~kg}}$ \\
\hline Berat volume $\left(\mathrm{W}_{2}-\mathrm{W}_{1}\right) / \mathrm{V}$ & $\begin{array}{c}(24,23-5,605) / 0,01 \\
=1.862,5 \mathrm{~kg} / \mathrm{m} 3\end{array}$ & $\begin{array}{c}(26,36-5,605) / 0,01 \\
=2.075,5 \mathrm{~kg} / \mathrm{m} 3\end{array}$ \\
\hline
\end{tabular}

Sumber: Hasil Uji Laboratorium Teknologi Bahan Fakultas Teknik Universitas Wiraraja Sumenep

Tabel 8. Hasil percobaan berat volume daerah Ellak Daya Lenteng

\begin{tabular}{|c|c|c|}
\hline DAERAH PERCOBAAN & $\begin{array}{c}\text { Desa Ellak Daya Lenteng } \\
\text { TANPA ROJOKAN }\end{array}$ & $\begin{array}{c}\text { Desa Ellak Daya Lenteng } \\
\text { DENGAN ROJOKAN }\end{array}$ \\
\hline Berat silinder $\left(\mathrm{W}_{1}\right)-\mathrm{kg}$ & $5,605 \mathrm{~kg}$ & $5,605 \mathrm{~kg}$ \\
\hline Berat batu pecah $\left(\mathrm{W}_{2}-\mathrm{W}_{1}\right)$ & $16,01 \mathrm{~kg}$ & $18,53 \mathrm{~kg}$ \\
\hline Berat silinder + batu pecah $\left(\mathrm{W}_{2}\right)-\mathrm{kg}$ & $5,605+16,01=21,61 \mathrm{~kg}$ & $5,605+18,53=24,13 \mathrm{~kg}$ \\
\hline Volume silinder $(\mathrm{V})-$ liter & 10 liter $=0,01 \mathrm{~m} 3$ & 10 liter $=0,01 \mathrm{~m} 3$ \\
\hline Berat volume $\left(\mathrm{W}_{2}-\mathrm{W}_{1}\right) / \mathrm{V}$ & $\begin{array}{c}(21,61-5,605) / 0,01 \\
=1.600,5 \mathrm{~kg} / \mathrm{m} 3\end{array}$ & $\begin{array}{c}(24,13-5,605) / 0,01 \\
=1.852,5 \mathrm{~kg} / \mathrm{m} 3\end{array}$ \\
\hline
\end{tabular}

Sumber: Hasil Uji Laboratorium Teknologi Bahan Fakultas Teknik Universitas Wiraraja Sumenep

Pengujian Kebersihan Agregat Terhadap Lumpur dengan Pencucian

Pengujian agregat kasar di laboratorium teknologi bahan untuk mengetahui karakteristik atau mutu dari agregat kasar (kerikil) yaitu percobaan kebersihan kerikil terhadap lumpur dengan pencucian, yang mana dalam percobaan ini untuk mengetahui kadar lumpur yang terkandung pada kerikil yang berasal dari Desa Batuan 
Jurnal Qua Teknika, Vol. 8 No. 2 September 2018

p-ISSN: 2088-2424; e-ISSN: 2527-3892

Fakultas Teknik Universitas Islam Balitar, Blitar

Http://qua.unisbablitar.ejournal.web.id; Email; quateknika@Gmail.com

Subaidillah Fansuri, Anita Intan Nura Diana. 2018. Karakteristik Komoditas Batu Kerikil dan Pasir Hitam untuk Bahan Bangunan di Kabupaten Sumenep.

Jurnal Qua Teknika, (2018), 8(2) : 43-51

(belakan asta tinggi), Desa Batu Putih, Desa Dasuk, Desa Duko, Desa Ellak Daya, berikut tabel data hasil percobaan kebersihan kerikil terhadap lumpur dengan cara pencucian yang di dapat dari hasil pengujian di laboratorium teknologi bahan Universitas Wiraraja Sumenep.

Tabel 9. Hasil percobaan berat volume daerah Ellak Daya Lenteng

\begin{tabular}{|c|c|c|c|c|c|}
\hline $\begin{array}{c}\text { DAERAH } \\
\text { PERCOBAAN }\end{array}$ & $\begin{array}{c}\text { Desa Batuan } \\
\text { (Belakang } \\
\text { asta tinggi) }\end{array}$ & $\begin{array}{l}\text { Desa Batu } \\
\text { Putih }\end{array}$ & Desa Dasuk & $\begin{array}{c}\text { Desa Duko } \\
\text { Rubaru }\end{array}$ & $\begin{array}{c}\text { Desa Ellak } \\
\text { Daya } \\
\text { Lenteng }\end{array}$ \\
\hline $\begin{array}{ll}\text { Berat kering belum } \\
\text { dicuci }\left(\mathrm{W}_{1}\right)\end{array}$ & $1 \mathrm{~kg}$ & $1 \mathrm{~kg}$ & $1 \mathrm{~kg}$ & $1 \mathrm{~kg}$ & $1 \mathrm{~kg}$ \\
\hline $\begin{array}{l}\text { Berat kering sesudah di } \\
\text { cuci }\left(\mathrm{W}_{2}\right)\end{array}$ & $0,990 \mathrm{~kg}$ & $0,995 \mathrm{~kg}$ & $0,995 \mathrm{~kg}$ & $0,995 \mathrm{~kg}$ & $0,993 \mathrm{~kg}$ \\
\hline $\begin{array}{l}\text { Kadar lumpur }=\left(\mathrm{W}_{1^{-}}\right. \\
\left.\mathrm{W}_{2}\right) / \mathrm{W}_{1} \times 100 \%\end{array}$ & $1 \%$ & $0,5 \%$ & $0,5 \%$ & $0,5 \%$ & $0,7 \%$ \\
\hline
\end{tabular}

Pengujian Keausan

Pengujian agregat kasar di laboratorium teknologi bahan untuk mengetahui karakteristik atau mutu dari agregat kasar (kerikil) yaitu percobaan keausan kerikil, yang mana dalam percobaan ini untuk mengetahui prosentasi keausan batu pecah/kerikil untuk beton yang berasal dari Desa Batuan (belakan asta tinggi), Desa Batu Putih, Desa Dasuk, Desa Duko, Desa Ellak Daya, berikut tabel data hasil percobaan keausan kerikil yang di dapat dari hasil pengujian di laboratorium teknologi bahan Universitas Wiraraja Sumenep.

Tabel 10. Hasil percobaan berat volume daerah Ellak Daya Lenteng

\begin{tabular}{|l|c|c|c|c|c|}
\hline \multicolumn{1}{|c|}{$\begin{array}{c}\text { DAERAH } \\
\text { PERCOBAAN }\end{array}$} & $\begin{array}{c}\text { Desa Batuan } \\
\text { ( Belakang } \\
\text { asta tinggi })\end{array}$ & $\begin{array}{c}\text { Desa Batu } \\
\text { Putih }\end{array}$ & Desa Dasuk & $\begin{array}{c}\text { Desa Duko } \\
\text { Rubaru }\end{array}$ & $\begin{array}{c}\text { Desa Ellak } \\
\text { Daya Lenteng }\end{array}$ \\
\hline $\begin{array}{l}\text { Berat } \\
\left(\mathrm{W}_{1}\right)\end{array}$ & $5 \mathrm{~kg}$ & $5 \mathrm{~kg}$ & $5 \mathrm{~kg}$ & $5 \mathrm{~kg}$ & $5 \mathrm{~kg}$ \\
\hline $\begin{array}{l}\text { Berat deselum diabrasi } \\
\left(\mathrm{W}_{2}\right)\end{array}$ & $4,01 \mathrm{~kg}$ & $3,52 \mathrm{~kg}$ & $3,69 \mathrm{~kg}$ & $3,76 \mathrm{~kg}$ & $3,72 \mathrm{~kg}$ \\
\hline $\begin{array}{l}\text { Keausan diabrasi } \\
\text { x 100\% }\end{array}$ & $19,8 \%$ & $29,6 \%$ & $26,2 \%$ & $24,8 \%$ & $25,6 \%$ \\
\hline
\end{tabular}

\section{Pengujian Material Agregat Halus (Pasir)}

Pengujian Kadar Air

Pengujian agregat halus di laboratorium teknologi bahan untuk mengetahui karakteristik atau mutu dari agregat halus (pasir) yaitu percobaan kadar air pasir, yang mana dalam percobaan ini untuk mengetahui berapa kandungan kadar air dalam pasir yang berasal dari Pasuruan dan Lumajang, berikut tabel data hasil percobaan kadar air yang di dapat dari hasil pengujian di laboratorium teknologi bahan Universitas Wiraraja Sumenep.

Tabel 11. Hasil Percobaan kadar air

\begin{tabular}{|l|c|c|}
\hline \multicolumn{1}{|c|}{$\begin{array}{c}\text { DAERAH } \\
\text { PERCOBAAN }\end{array}$} & Pasir Pasuruan & $\begin{array}{c}\text { Pasir } \\
\text { Lumajang }\end{array}$ \\
\hline Berat kerikil asli (W $\left.\mathrm{W}_{1}\right)$ & $500 \mathrm{gr}$ & $500 \mathrm{gr}$ \\
\hline $\begin{array}{l}\text { Berat kerikil kering oven } \\
\left(\mathrm{W}_{2}\right)\end{array}$ & $438 \mathrm{gr}$ & $459 \mathrm{gr}$ \\
\hline $\begin{array}{l}\text { Kelembaban kerikil } \\
\left(\mathrm{W}_{1}-\mathrm{W}_{2}\right) / \mathrm{W}_{2} \times 100 \%\end{array}$ & $14,15 \%$ & $8,93 \%$ \\
\hline
\end{tabular}


Jurnal Qua Teknika, Vol. 8 No. 2 September 2018

p-ISSN: 2088-2424; e-ISSN: 2527-3892

Fakultas Teknik Universitas Islam Balitar, Blitar

Http://qua.unisbablitar.ejournal.web.id; Email; quateknika@ Gmail.com

Subaidillah Fansuri, Anita Intan Nura Diana. 2018. Karakteristik Komoditas Batu Kerikil dan Pasir Hitam untuk Bahan Bangunan di Kabupaten Sumenep.

Jurnal Qua Teknika, (2018), 8(2) : 43-51

Hasil penelitian yang kami lakukan dalam percobaan kadar air pasir ini didapatkan hasil kandungan kadar air pasir yang berbeda-beda dari setiap daerah pasir yang kami teliti

Pengujian Berat Jenis

Pengujian agregat halus di laboratorium teknologi bahan untuk mengetahui karakteristik atau mutu dari agregat halus (pasir) yaitu percobaan berat jenis pasir, yang mana dalam percobaan ini untuk mengetahui berat jenis kering,berat jenis SSD (Saturated Surface Dry), berat jenis semu dan penyerapan air pada pasir yang berasal dari pasuruan dan Pasirian Lumajang, berikut tabel data hasil percobaan berta jenis yang di dapat dari hasil pengujian di laboratorium teknologi bahan Universitas Wiraraja Sumenep.

Tabel 12. Hasil Percobaan berat jenis

\begin{tabular}{|l|c|c|}
\hline \multicolumn{1}{|c|}{ DAERAH PERCOBAAN } & Pasir Lumajang & Pasir Pasuruan \\
\hline Berat labu + pasir + air $\left(\mathrm{W}_{1}\right)$ & $1029,5 \mathrm{gr}$ & $995,5 \mathrm{gr}$ \\
\hline Berat pasir SSD & $500 \mathrm{gr}$ & $500 \mathrm{gr}$ \\
\hline Berat labu + air $\left(\mathrm{W}_{2}\right)$ & $704,5 \mathrm{gr}$ & $704,5 \mathrm{gr}$ \\
\hline Berat pasir kering oven $\left(\mathrm{W}_{3}\right)$ & $490 \mathrm{gr}$ & $475,1 \mathrm{gr}$ \\
\hline Berat jenis kering $=\mathrm{W}_{3} /\left(\mathrm{W}_{2}+500-\mathrm{W}_{1}\right)$ & $2,8 \mathrm{gr}$ & $2,27 \mathrm{gr}$ \\
\hline Berat Jenis $\mathrm{SSD}=500 /\left(\mathrm{W}_{2}+500-\mathrm{W}_{1}\right)$ & $2,85 \mathrm{gr}$ & $2,39 \mathrm{gr}$ \\
\hline Berat Jenis Semu $=\mathrm{W}_{3} /\left(\mathrm{W}_{2}+\mathrm{W}_{3}-\mathrm{W}_{1}\right)$ & $2,96 \mathrm{gr}$ & $2,58 \mathrm{gr}$ \\
\hline Penyerapan $=\left(\left(500-\mathrm{W}_{3}\right) / 500\right) \times 100 \%$ & $2 \%$ & $4,98 \%$ \\
\hline
\end{tabular}

Hasil penelitian yang kami lakukan dalam percobaan berat jenis pasir ini didapatkan hasil berat jenis kering pasir, berat jenis SSD pasir, berat jenis semu pasir dan penyerapan air pada pasir yang berbeda-beda dari setiap daerah

\section{Pengujian Berat Volume}

Pengujian agregat halus di laboratorium teknologi bahan untuk mengetahui karakteristik atau mutu dari agregat halus (pasir) yaitu percobaan berat volume pasir, yang mana dalam percobaan ini untuk mengetahui berat volume pasir yang berasal dari pasuruan dan pasir pasirian lumajang berikut tabel data hasil percobaan berta jenis yang di dapat dari hasil pengujian di laboratorium teknologi bahan Universitas Wiraraja Sumenep.

Tabel 13. Hasil pengujian berat volume daerah Pasuruan

\begin{tabular}{|l|c|c|}
\hline \multicolumn{1}{|c|}{ DAERAH PERCOBAAN } & $\begin{array}{c}\text { Pasir Pasuruan } \\
\text { TANPA ROJOKAN }\end{array}$ & $\begin{array}{c}\text { Pasir Pasuruan } \\
\text { DENGAN ROJOKAN }\end{array}$ \\
\hline Berat silinder $\left(\mathrm{W}_{1}\right)-\mathrm{kg}$ & $2,887 \mathrm{~kg}$ & $2,887 \mathrm{~kg}$ \\
\hline Berat pasir $\left(\mathrm{W}_{2}-\mathrm{W}_{1}\right)$ & $3,967 \mathrm{~kg}$ & $4,378 \mathrm{~kg}$ \\
\hline Berat silinder + batu pecah $\left(\mathrm{W}_{2}\right)-\mathrm{kg}$ & $2,887+3,967=6,854 \mathrm{~kg}$ & $2,887+4,378=7,265 \mathrm{~kg}$ \\
\hline Volume silinder $(\mathrm{V})-$ liter & 3 liter $=0,003 \mathrm{~m} 3$ & 3 liter $=0,003 \mathrm{~m} 3$ \\
\hline Berat volume $\left(\mathrm{W}_{2}-\mathrm{W}_{1}\right) / \mathrm{V}$ & $\begin{array}{c}(6,854-2,887) / 0,003 \\
=1.322,3 \mathrm{~kg} / \mathrm{m} 3\end{array}$ & $\begin{array}{c}(7,265-2,887) / 0,003 \\
=1.459,3 \mathrm{~kg} / \mathrm{m} 3\end{array}$ \\
\hline
\end{tabular}

Sumber: Hasil Uji Laboratorium Teknologi Bahan Fakultas Teknik Universitas Wiraraja Sumenep 
Jurnal Qua Teknika, Vol. 8 No. 2 September 2018

p-ISSN: 2088-2424; e-ISSN: 2527-3892

Fakultas Teknik Universitas Islam Balitar, Blitar

Http://qua.unisbablitar.ejournal.web.id; Email; quateknika@ Gmail.com

Subaidillah Fansuri, Anita Intan Nura Diana. 2018. Karakteristik Komoditas Batu Kerikil dan Pasir Hitam untuk Bahan Bangunan di Kabupaten Sumenep.

Jurnal Qua Teknika, (2018), 8(2) : 43-51

Tabel 14. Hasil pengujian berat volume daerah Lumajang

\begin{tabular}{|c|c|c|}
\hline DAERAH PERCOBAAN & $\begin{array}{c}\text { Pasir Lumajang } \\
\text { TANPA ROJOKAN }\end{array}$ & $\begin{array}{c}\text { Pasir Lumajang } \\
\text { DENGAN ROJOKAN }\end{array}$ \\
\hline Berat silinder $\left(\mathrm{W}_{1}\right)-\mathrm{kg}$ & $2,887 \mathrm{~kg}$ & $2,887 \mathrm{~kg}$ \\
\hline Berat pasir $\left(\mathrm{W}_{2}-\mathrm{W}_{1}\right)$ & $4,493 \mathrm{~kg}$ & $5,248 \mathrm{~kg}$ \\
\hline Berat silinder + batu pecah $\left(\mathrm{W}_{2}\right)-\mathrm{kg}$ & $2,887+4,493=7,380 \mathrm{~kg}$ & \begin{tabular}{c}
$2,887+5,248=8,135 \mathrm{~kg}$ \\
\hline Volume silinder $(\mathrm{V})-$ liter
\end{tabular} \\
\hline Berat volume $\left(\mathrm{W}_{2}-\mathrm{W}_{1}\right) / \mathrm{V}$ & $\begin{array}{c}(7,380-2,887) / 0,003 \\
=1.497,6 \mathrm{~kg} / \mathrm{m} 3\end{array}$ & $\begin{array}{c}(8,135-2,887) / 0,003 \\
=1.749,3 \mathrm{~kg} / \mathrm{m} 3\end{array}$ \\
\hline
\end{tabular}

Sumber: Hasil Uji Laboratorium Teknologi Bahan Fakultas Teknik Universitas Wiraraja Sumenep

Hasil penelitian yang kami lakukan dalam percobaan berat volume pasir ini didapatkan hasil berat volume pasir dengan dirojok maupun tanpa rojak yang berbeda-beda dari setiap daerah pasir yang kami teliti

Pengujian Kebersihan Pasir Terhadap Lumpur dengan Pengendapan

Langkah keempat dalam pengujian agregat halus di laboratorium teknologi bahan untuk mengetahui karakteristik atau mutu dari agregat halus (pasir) yaitu percobaan kebersihan pasir terhadap lumpur (pengendapan), yang mana dalam percobaan ini untuk mengetahui kadar lumpur pasir yang berasal dari pasuruan dan pasir pasirian lumajang, berikut tabel data hasil percobaan kebersihan pasir terhadap lumpur (pengendapan) yang di dapat dari hasil pengujian di laboratorium teknologi bahan Universitas Wiraraja Sumenep.

Tabel 15. Hasil Pengujian Kebersihan Agregat Halus Terhadap Lumpur (pengendapan)

\begin{tabular}{|l|c|c|}
\hline $\begin{array}{c}\text { DAERAH } \\
\text { PERCOBAAN }\end{array}$ & Pasir Pasuruan & $\begin{array}{c}\text { Pasir } \\
\text { Lumajang }\end{array}$ \\
\hline Tinggi lumpur $(\mathrm{h})$ & $0,3 \mathrm{~cm}$ & $0,5 \mathrm{~cm}$ \\
\hline Tinggi pasir $(\mathrm{H})$ & $5,7 \mathrm{~cm}$ & $5,5 \mathrm{~cm}$ \\
\hline Kadar lumpur $=\mathrm{h} / \mathrm{H}$ & $5,26 \%$ & $9 \%$ \\
\hline
\end{tabular}

Hasil penelitian yang kami lakukan dalam percobaan kebersihan pasir terhadap lumpur (pengendapan) ini didapatkan hasil kebersihan pasir terhadap lumpur (pengendapan) yang berbeda-beda dari setiap daerah pasir yang kami teliti

Pengujian Kebersihan Pasir Terhadap Lumpur dengan Pencucian

Pengujian agregat halus di laboratorium teknologi bahan untuk mengetahui karakteristik atau mutu dari agregat halus (pasir) yaitu percobaan kebersihan pasir terhadap lumpur (pencucian), yang mana dalam percobaan ini untuk mengetahui kadar lumpur pasir yang berasal dari pasuruan dan pasir pasirian lumajang, berikut tabel data hasil percobaan kebersihan pasir terhadap lumpur (pencucian) yang di dapat dari hasil pengujian di laboratorium teknologi bahan Universitas Wiraraja Sumenep.

Tabel 16. Pengujian Kebersihan Agregat Halus Terhadap Lumpur (pencucian)

\begin{tabular}{|l|c|c|}
\hline \multicolumn{1}{|c|}{ DAERAH PERCOBAAN } & $\begin{array}{c}\text { Pasir Pasirian } \\
\text { Lumajang }\end{array}$ & $\begin{array}{c}\text { Pasir Pasirian } \\
\text { Pasuruan }\end{array}$ \\
\hline Berat pasir kering (W1) & $500 \mathrm{gr}$ & $500 \mathrm{gr}$ \\
\hline Berat pasir bersih kering (W2) & $460,5 \mathrm{gr}$ & $468,7 \mathrm{gr}$ \\
\hline Kadar lumpur (W1-W2)/W1x 100\% & $7,9 \%$ & $6,26 \%$ \\
\hline
\end{tabular}

Hasil penelitian yang kami lakukan dalam percobaan kebersihan pasir terhadap lumpur (pencucian) ini didapatkan hasil kebersihan pasir terhadap lumpur (pencucian) yang berbeda-beda dari setiap daerah pasir yang kami teliti. 
Jurnal Qua Teknika, Vol. 8 No. 2 September 2018

p-ISSN: 2088-2424; e-ISSN: 2527-3892

Fakultas Teknik Universitas Islam Balitar, Blitar

Http://qua.unisbablitar.ejournal.web.id; Email; quateknika@Gmail.com

Subaidillah Fansuri, Anita Intan Nura Diana. 2018. Karakteristik Komoditas Batu Kerikil dan Pasir Hitam untuk Bahan Bangunan di Kabupaten Sumenep.

Jurnal Qua Teknika, (2018), 8(2) : 43-51

\section{SIMPULAN}

Berdasarkan hasil penelitian yang telah dilakukan tentang karakteristik komoditas agregat kasar (batu kerikil) dan agregat halus (pasir hitam) untuk bahan bangunan di kabupaten sumenep dapat diambil kesimpulan sebagai berikut :

A. Percobaan agregat kasar

1. Hasil percobaan kadar air agregat kasar untuk Desa Batuan 5,02\%; Desa Batu Putih 1,83\%; Desa Dasuk 2,08\%; Desa Rubaru 1,93\%; Desa Lenteng 2,04\%.

2. Hasil percobaan berat jenis kering agregat kasar untuk Desa Batuan 2,42 gr; Desa Batu Putih 2,39 gr; Desa Dasuk 2,45 gr; Desa Rubaru 2,53 gr; Desa Lenteng 2,32 gr.

3. Hasil percobaan berat volume agregat kasar untuk Desa Batuan 1814,5 Kg/m3; Desa Batu Putih 2230,5 Kg/m3; Desa Dasuk 1977,5 Kg/m3; Desa Rubaru 2075,5 Kg/m3; Desa Lenteng 1852,5 Kg/m3.

4. Hasil percobaan kebersihan agregat terhadap kadar lumpur agregat kasar untuk Desa Batuan $1 \%$; Desa Batu Putih 0,5 \% ; Desa Dasuk 0,5 \%; Desa Rubaru 0,5 \%; Desa Lenteng 0,7 \%.

5. Hasil percobaan keausan agregat kasar untuk Desa Batuan 19,8 \%; Desa Batu Putih 29,6\% ; Desa Dasuk 26,2 \%; Desa Rubaru 24,8 \%; Desa Lenteng 25,6\%.

B. Percobaan agregat halus

1. Hasil percobaan kadar air agregat halus untuk pasir pasuruan $14,15 \%$; dan pasir pasirian $8,93 \%$.

2. Hasil percobaan berat jenis kering agregat halus untuk pasir pasuruan $2,27 \mathrm{gr}$; dan pasir pasirian $2,8 \mathrm{gr}$.

3. Hasil percobaan berat volume agregat halus untuk pasir pasuruan $1459,3 \mathrm{Kg} / \mathrm{m} 3$; dan pasir pasirian $1749,3 \mathrm{Kg} / \mathrm{m} 3$.

4. Hasil percobaan kadar lumpur (pengendapan) agregat halus untuk pasir pasuruan 5,26\%; dan pasir pasirian $9 \%$.

5. Hasil percobaan kadar lumpur (pencucian) agregat halus untuk pasir pasuruan 6,26\%; dan pasir pasirian $7,9 \%$.

\section{REFERENSI}

Lamudi. 2014. "Pengertian dan Jenis Pasir", (Online). (http://www.lamudi.co.id/journal5-jenis-pasir-untukbahan-bangunan/ diakses 2 Maret 2016).

(SK.SNI. T-15-1990:1) Klasifikasi Agregat, "berat jenis dan berat isi volume"

(SNI S-04-1989-F), "Kadungan Lumpur Untuk Agregat Kasar"

(SNI 1737-1989-F), "Standart Kehancuran Agregat Kasar dengan Mesin Abrasi Los Angel"

(SNI S-04-1989-F), "Kadungan Lumpur Untuk Agregat Halus (Pengendapan)"

(PBI 1971 N.I-2, pasal 3.3 ayat 3 agregat halus (pasir) ), "Kadungan Lumpur Untuk Agregat Halus (Pencucian)"

Panitia Penyusun Pedoman. 2017. Buku Pedoman Praktikum Teknologi Bahan Konstruksi "Kegiatan Praktikum". Program Studi Teknik Sipil, Universitas Wiraraja Sumenep.

Andriawan,Valentino Rio. September 2014. Pengaruh Volume Agregat Halus Terhadap Sifat Segar dan Kuat Tekan Pada High Volume Fly Ash Concrete (HVFAC). E-Jurnal Matriks Teknik Sipil

Salain, I Made Alit Karyawan. Februari 2009. Pengaruh Jenis Semen dan Jenis Agregat Kasar Terhadap Kuat Tekan Beton. Jurnal Teknologi dan Kejuruan Vol.32, No.1

Handojo, Julistiono,dkk. September 2001. Potensi Pemakaian Kerikil Paterongan, Torjun, dan Omben Di Pulau Madura Untuk Beton Struktur. Jurnal Dimensi Teknik Sipil Vol.3 No.2, ISSN 1410-9530

Polii, Reza Adeputra. Maret 2015. Kuat Tekan Beton Dengan Variasi Agregat Yang Berasal Dari Beberapa Tempat di Sulawesi Utara. Jurnal Sipil Statik Vol.3 No.3, ISSN 2337-6732 